\title{
高速列車が明かり区間を走行する際に生じる低周波音*
}

\author{
高見 創*1, 菊 地勝 浩*1, 前川 博*2 \\ 栗田健*3, 若 林雄 介*3

\section{Low-Frequency Noise Radiated from a High-Speed Train Passing an Open Section}

\author{
Hajime TAKAMI*4, Katsuhiro KIKUCHI, Hiroshi MAEKAWA, \\ Takeshi KURITA and Yusuke WAKABAYASHI \\ ${ }^{*}$ Railway Technical Research Institute, Environmental Engineering Division, \\ 2-8-38 Hikari-cho, Kokubunji-shi, Tokyo, 185-8540 Japan
}

\begin{abstract}
It is reported that not only an audible noise but also a low-frequency noise including an infrasound is radiated from a high-speed train (called Shinkansen in Japan) toward a wayside open area. Although these noises become larger as the train speed increases, the cause of the lowfrequency noise remains to be fully clarified. In this study, we investigated the wayside low-frequency noise at two sites: a viaduct section and an embankment section. The investigation results show that the observed low-frequency noise consists of two phenomena ; the one is a train passing pressure variation around the nose and tail parts of the train; the other is a low-frequency acoustic pressure wave caused not only by an aerodynamic source around the train but also by a viaduct vibration. The maximum sound pressure level of the low-frequency noise is determined by these phenomena which have different magnitude depending on the train speed, a measurement distance and a type of running section. Furthermore, the characteristic of the measured low-frequency noise in a high-speed region, which is analogous to a line source, shows that the low-frequency noise is mainly related to the aerodynamic sound emitted from all over the train.
\end{abstract}

Key Words: Railway, Low-Frequency Noise, Infrasound, Fluctuating Pressure, Noise, Sound and Acoustic

\section{1.はじめに}

近年の産業界において騒音問題として取り上げられ る低周波音(1) とは, $20 \mathrm{~Hz}$ 以下の超低周波音を含む周波 数が $1 \sim 100 \mathrm{~Hz}$ 程度の低い圧力変動 (低周波空気振動) を指している. 一般に, 低周波音は人の感覚閾值が高 く(感じ難く), 可聴域騒音と比べ問題になることは少 ないものの, 音圧レベルが大きい場合には家屋などの 建具をガタつかせたり，人体に対して圧迫感や耳鳴り などの心理的影響を及ぼしたりする場合がある.また, 一旦問題になると，その波長の長さから可聴域騒音の ような防音・遮音対策は困難である場合が多く, 問題

* 原稿受付 2007 年 5 月 9 日.

*1 正員, 鉄道総合技術研究所(亚 185-8540 国分寺市光町 2-8 38).

*2 正員, フェロー, 広島大学大学院工学研究科(亚 739-8527 東 広島市鏡山 1-4-1).

*3 正員, JR 東日本研究開発センター(画331-8513 さいたま市 北区日進町 2-0).

E-mail : takami@rtri.or.jp
の解決には低周波音の発生源対策が有効となる(2). 新幹線に代表される高速鉄道の沿線では, 列車がト ンネルへ突入する際に生じるパルス状の圧力波により 低周波音問題を引き起こす事例が報告され，対策が進 んでいる(3).一方で, トンネル以外の明かり区間で低 周波音が環境問題となった事例はほとんど報告されて いない，しかし，今後列車の高速化が進むなどした場 合には，トンネルに比べ明かり区間沿線には家屋が数 多く近接しており，問題が顕在化することも考えられ る.

このような背景から，環境省が提示した「低周波音 の測定方法に関するマニュアル(4)」(以下，環境省マニ ユアル)に従った測定量 ( $\mathrm{G}$ 特性音圧レベル, 1/3オク ターブバンド音圧レベル, 時定数 SLOW）が, 明かり 区間の鉄道沿線で調查された (5). その知見から, 鉄道 沿線において観測される低周波音は, 現象面から図 1 に示す二つの現象へ分けることができる. 


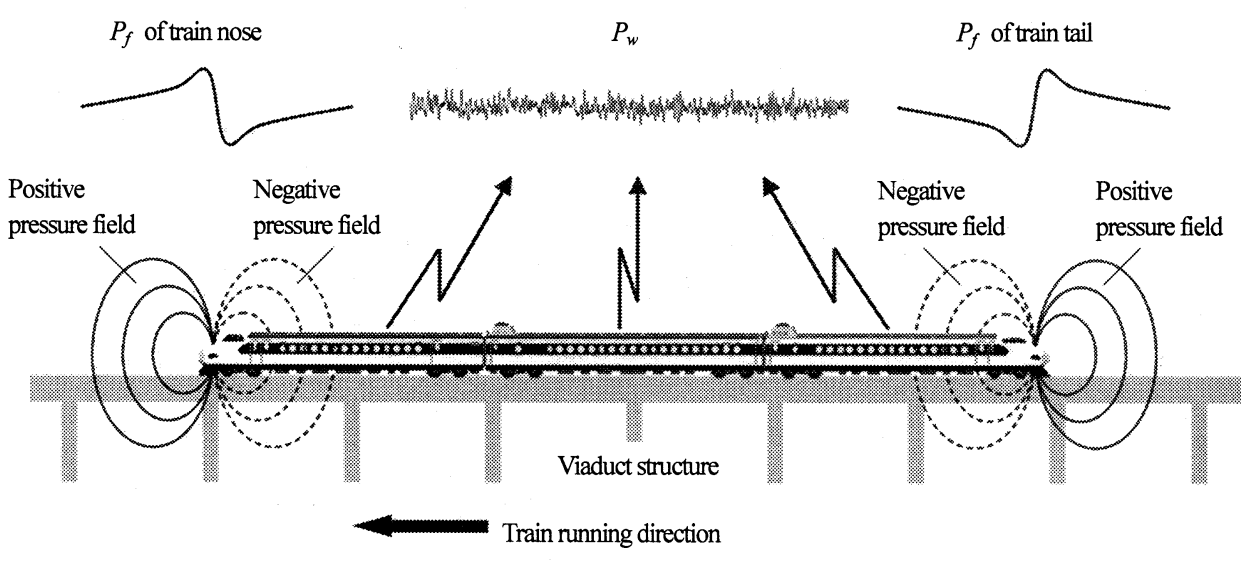

Fig. 1 Schematic diagram of the low-frequency noise radiated from the train. $P_{f}$ means the 'passing pressure variation' caused by the moving quasi-steady pressure field around the train. $P_{w}$ means the 'low-frequency acoustic pressure wave' caused not only by the aerodynamic source but also by the viaduct vibration.

一つは，「列車通過時圧力変動(6(7)」と呼ばれる現象 である.これは主に列車の先頭部や後尾部に発生する 準静的な圧力場が，列車とともに移動することで生じ る擬似音である，本論文では，便宜的にこの現象を $\left\lceil P_{f}\right\rfloor$ と記述する. $P_{f}$ による圧力変動は，簡易的には 列車先頭部を一点わき出しでモデル化した次式で表さ れる(8).

$$
p(\mathbf{x}, t)=-\frac{\rho_{0} U^{2} A_{0}}{2 \pi} \frac{\cos (\mathbf{x},-U t)}{r^{2}(\mathbf{x},-U t)}
$$

ここで, $\rho_{0}$ : 空気密度, $U$ : 列車速度, $A_{0}$ : 列車断面 積, $\cos (\mathbf{x},-U t)$ は時間 $t$ におけるわき出しの位置と観 測点 $\mathbf{x}$ を結んだ線が列車先頭から後尾へ向かう軸とな す角による余弦を表し, $r(\mathbf{x},-U t)$ はわき出しから観測 点までの距離である.

もう一つは, 「音響学的低周波音」と呼ぶ数十 $\mathrm{Hz}$ 程 度の波動現象 (音波)である.この現象を便宜的に「 $\left.P_{w}\right\rfloor$ 之記述する. $P_{w}$ の発生原因については不明な点も多い が, 現段階では列車周りの空気の流れが乱れることで 生じる空力音と,構造物の振動により生じる固体音(以 下，構造物音）が混在したものと考えられている(9).

本研究では，明かり区間を高速列車が通過する際に 生じる低周波音を，環境省マニュアルとは異なり，音 源の特性把握を主眼とした測定方法により実施した現 地測定結果について報告する. また, 列車速度, 観測 距離，走行区間（高架区間と盛土区間）が異なる場合 の結果を比較・検討し, 高速列車の沿線で観測される 低周波音のより一般的な特性について示す.

\section{2. 測 定 概 要}

測定は新幹線沿線の明かり区間において，構造物が コンクリート高架橋の高架区間と，土を盛り上げた盛 土区間の二箇所で行った. 図 2(a)に示す高架区間は, 高架橋の高さが約 $15 \mathrm{~m}$ で, 高架上の線路両側には高 さ約 $1 \mathrm{~m}$ の直壁形防音壁が備わっている. また, 線形 は直線で, 軌道構造はスラブ軌道である. 図 2(b)に示 す盛土区閒は，水平面に対する傾斜角約 $40^{\circ}$ ，高さ約 $8 \mathrm{~m}$ の植生法面を両側に有し, 線路の両側に高さ約 $2 \mathrm{~m}$ の直壁形防音壁が備わっている．また，線形は R6000 の緩い曲線区間で, 軌道構造はバラスト軌道である。

低周波音の測定には，超低周波音圧レベル計（リオ 製 $\mathrm{XN}-12 \mathrm{~A}$ ，周波数範囲 $0.2 \sim 1,000 \mathrm{~Hz}$ ）を使用し， 一部の観測点については，環境省マニュアルに準拠し た低周波音圧レベル計 ${ }^{(10)}$ （リオン製 NA-18A，周波数 範囲 $1 \sim 500 \mathrm{~Hz}$ ）を使用した. 図 2 に示寸距離 $r$ は, 観測点から列車中心軸までを見通した直線距離である。 また，精密騷音計（リオン製 NL-32，周波数範囲 20 $20,000 \mathrm{~Hz})$ を盛土区間の線路と平行に 5 台並べて配置 し，指向性マイクロホンアレイとして使用した. ここ で, 各マイクロホンの間隔は目的とする音波の波長の $1 / 2$ に選んだ.

高架区間における構造物音の影響は，図 2(a)に示す 桁中央下面の振動速度を，振動計（リオン製 UV-05, PV-95, 周波数範囲 1 10,000 Hz) により測定すること で調べた.

これらの音圧および振動データは, 列車の通過タイ 
(a) Viaduct section

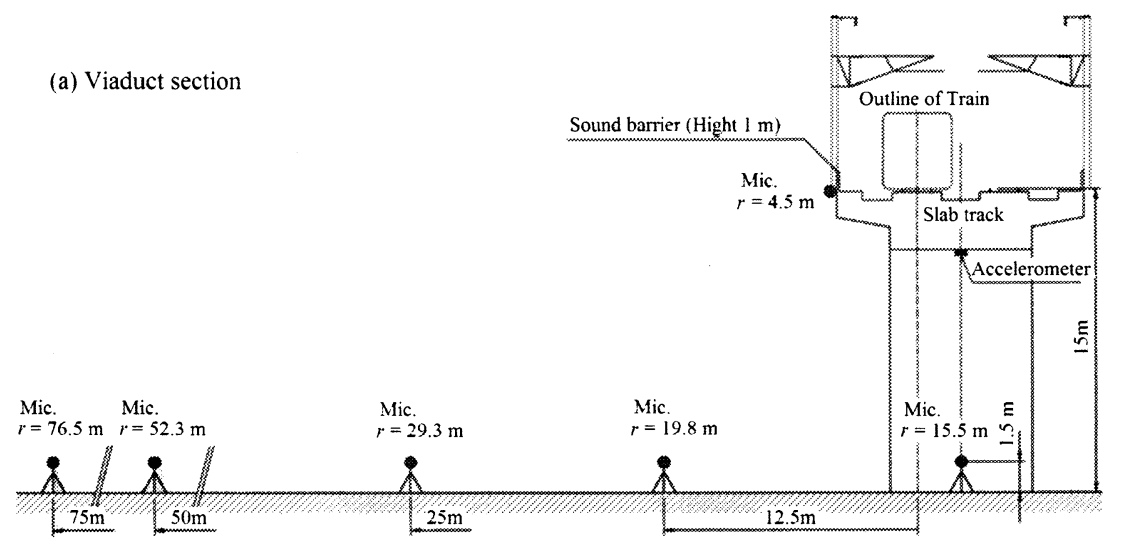

(b) Embankment section

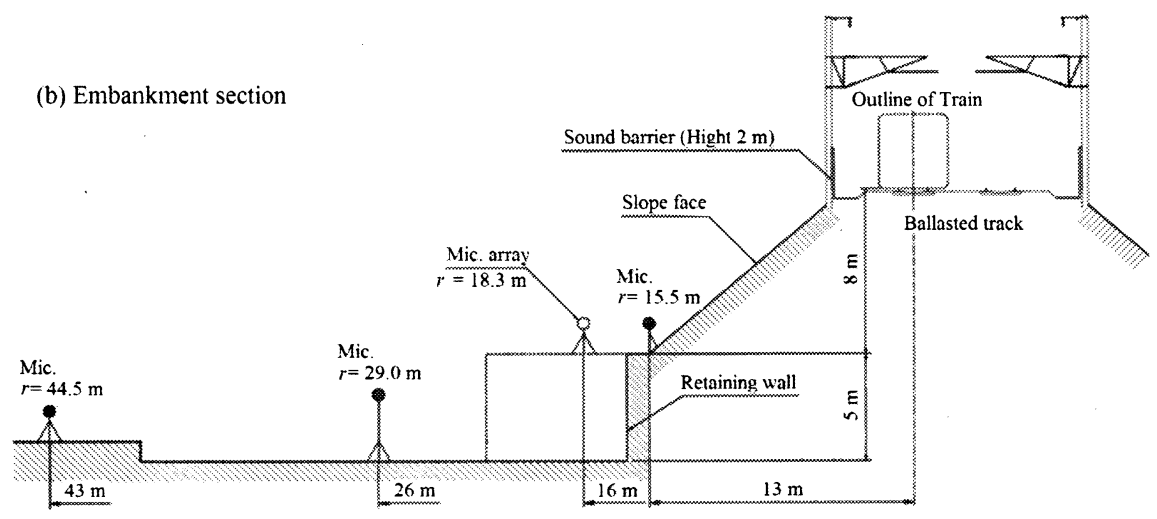

Fig. 2 Schematic diagrams of measurement sites at (a) viaduct section and (b) embankment section; microphones (•) are low-frequency sound level meters, and microphone $(\circ)$ is directivity microphone-array.

ミングを測る車軸通過信号とともに時間歴波形として デジタルオーディオレコーダ（ソニー製 PC-216Ax, 周波数範囲 $\mathrm{DC} \sim 5 \mathrm{kHz}$ ) へ記録し, その後, 所定の区 間の音圧レベルの算出や周波数分析を行った.

測定した列車の主な諸元を表 1 に示す. 列車は 3 種 類あるが, Type-A と Type-B は測定地点においては併結 されており (以降, Type-ABで表す), 測定時の進行方 向に対して Type-A が先行車, Type-Bが後続車となる. Type-Cは高速試験車で空力的にも滑らかな形状をもち, Type-A や Type-B よりも高速で走行する.

Table 1 Specifications of the trains.

\begin{tabular}{c|cc|c}
\hline Train type & Type- $A$ & Type- $B$ & Type-C \\
\hline Cross-sectional area & $10.3 \mathrm{~m}^{2}$ & $11.2 \mathrm{~m}^{2}$ & $10.8 \mathrm{~m}^{2}$ \\
Nose length & $6 \mathrm{~m}$ & $8.9 \mathrm{~m}$ & $16 \mathrm{~m}$ \\
& $146 \mathrm{~m}$ & $250 \mathrm{~m}$ & $200 \mathrm{~m}$ \\
Overall length & $(6 \mathrm{cars})$ & $(10 \mathrm{cars})$ & $(8 \mathrm{cars})$ \\
Speed range & \multicolumn{2}{|c|}{$150-270 \mathrm{~km} / \mathrm{h}$} & $270-400 \mathrm{~km} / \mathrm{h}$ \\
\hline
\end{tabular}

\section{3. 測 定 結 果}

3-1 測定波形 音圧 (単位: $\mathrm{Pa}$ ) およひ僢時音 圧レベル (単位: dB, 平坦特性 1 $100 \mathrm{~Hz}$, 動特性 FAST, 時定数 $0.125 \mathrm{~s}$ ）の波形を図 3 に示す．ここで, 瞬時音 圧レベルは，同条件の複数列車 (10 列車程度) につい て車軸通過信号で同期をとったアンサンブルパワー平 均值である. また, 図の上部に示す列車の模式図は, 列車 Type-AB の先頭部／併結部／後尾部が測定点の正 面を通過する時間と観測波形の対応を示す（図 4, 5,8 も同様). なお，高架区間と盛土区間の観測距離 $\boldsymbol{r}$ は, 設置場所の都合から同一ではない点に留意されたい.

図 3 に示寸音圧波形において, 列車の先頭部および 後尾部の通過時に生じる振幅の大きい圧力変動が, 列 車周りの準静的圧力場により生じる現象 : $P_{f}$ である. 一方, 列車の通過中に継続して生じる振幅の小さい压 力変動が, 音響学的低周波音: $P_{w}$ である. これらの現 象に対応し，瞬時音圧レベルは，近傍場では先頭・後 

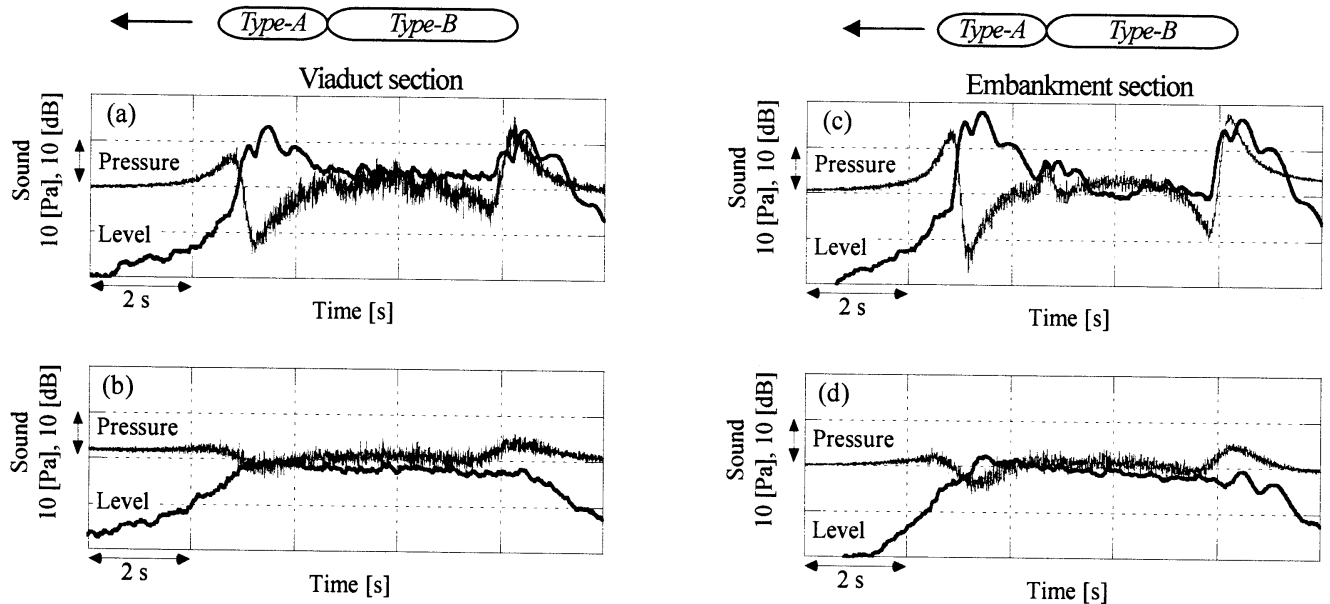

Fig. 3 Time histories of sound pressure (-) and SPL $(-)$ in (a) near field ( $r=19.8 \mathrm{~m})$ of viaduct section, (b) far field $(r=$ $52.3 \mathrm{~m}$ ) of viaduct section, (c) near field $(r=15.5 \mathrm{~m})$ of embankment section, and (d) far field $(r=44.5 \mathrm{~m})$ of embankment section.

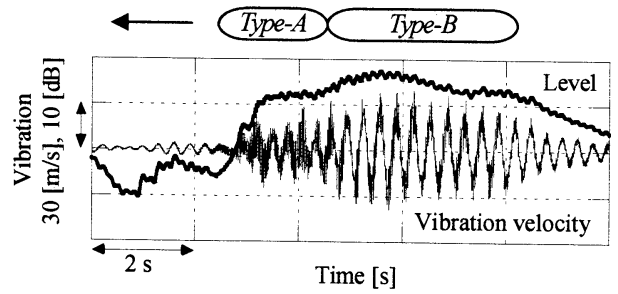

Fig. 4 Time histories of vibration velocity $(-)$ and vibration level (-) on the lower surface of the girder at viaduct section.

尾通過時に二つの明確なピークを示し，遠方場ではピ ークのないほぼ一定の值を示すようになる.

図 2(a)に示す桁中央の下面で測定した高架橋の振動 速度 (単位: $\mathrm{m} / \mathrm{s}$ ) およひ僢時振動レベル (単位: $\mathrm{dB}$, 平坦特性, 時定数 $0.125 \mathrm{~s}$ ) の波形を図 4 に示す. なお, 振動レベルは，音圧レベルと同様に複数列車を平均し た值である. 図 4 の振動速度波形から, 列車の通過中 および通過後に, 構造物の周期的な振動が認められる.

\section{3-2 周波数分析 観測された音の周波数と時間} に関する情報を得るため, 音圧のパワースペクトル密 度を同条件の複数列車についてアンサンブルパワー平 均したスペクトログラムを, 図 5 に示す.ここで, 先 頭部・併結部・後尾部に生じている $3 \mathrm{~Hz}$ 以下の超低周 波音は, $P_{f}$ による擬似音である.これら擬似音を除外 すると, 高架区間と盛土区間ではともに $10 \sim 40 \mathrm{~Hz}$ 程 度に周波数幅の広い音波成分があり，かつ高架区間で は構造物音と考えられるピークの鋭い成分（図 5(a)の
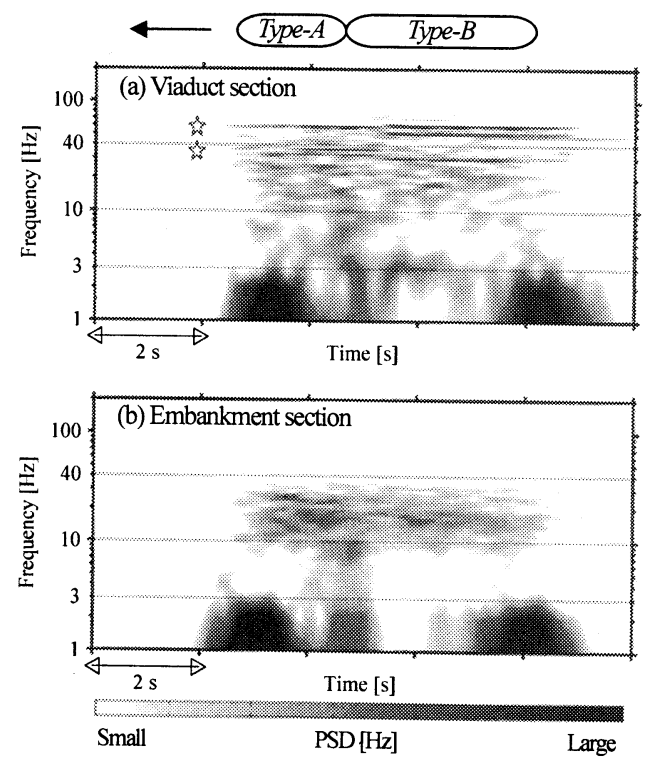

Fig. 5 Spectrogram of sound pressure at (a) viaduct section and (b) embankment section; $U=270 \mathrm{~km} / \mathrm{h}, r \approx 29 \mathrm{~m}$.

泖）も加わることが分かる.

列車通過中の $1 / 3$ オクターブバンド等価音圧レベル （動特性 FAST，時定数 $0.125 \mathrm{~s}$ ) を，図 6(a)に示す. 高架区間と盛土区間の音の周波数分布を比較すると, $30 \mathrm{~Hz}$ 以上の成分が高架区間は盛土区間よりも明らか に大きいことが分かる．また，高架区間における振動 の周波数分布は (図 6b)，3 Hz と $30 \mathrm{~Hz}$ にピークがあ り，また $40 \mathrm{~Hz}$ 以上の成分も大きい，なお，構造物の 

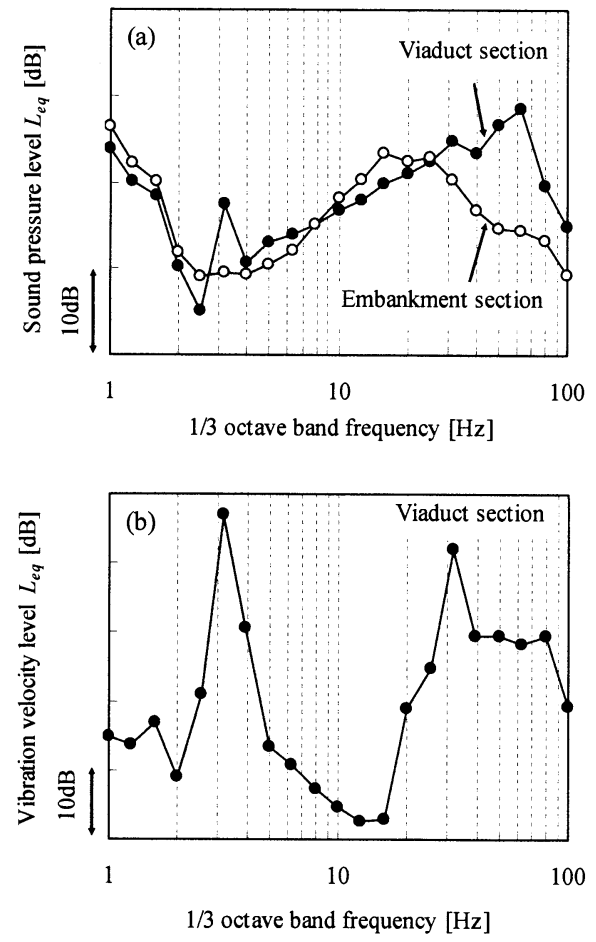

Fig. 6 Spectra of (a) sound pressure level at $r \approx 29 \mathrm{~m}$ and (b) viaduct vibration level on the lower surface of the girder; train Type- $A B, U=270 \mathrm{~km} / \mathrm{h}$.

固有振動数は構造や基礎形式の違い, 地盤のバネ值等 が関係し，計算で容易に求めることは困難である.た だし，一次固有振動数に関しては過去の実験データ から 3 6 Hz 程度が一般的であり，高架区間において 卓越した $3 \mathrm{~Hz}$ の成分は高架橋の一次固有振動数と見 なせる. また, $30 \mathrm{~Hz}$ の成分をはじめとしたより高周 波の成分は，構造物が持つ高次の振動モードと考えら れる.

ここで，それぞれの信号間の相関（振幅二乗コヒー レンス関数 $) \Gamma(\Omega)$ を次式で定義する.

$$
\begin{gathered}
\Gamma_{p p^{\prime}}(\Omega)=\frac{\left|S_{p p^{\prime}}(\Omega)\right|^{2}}{S_{p}(\Omega) S_{p^{\prime}}(\Omega)} \\
\Gamma_{p v}(\Omega)=\frac{\left|S_{p v}(\Omega)\right|^{2}}{S_{p}(\Omega) S_{v}(\Omega)}
\end{gathered}
$$

ただし, $S_{p}(\Omega), S_{p^{\prime}}(\Omega)$ は周波数 $\Omega$ に関する音のパワー スペクトル密度関数, $S_{v}(\Omega)$ は振動速度のパワースペ クトル密度関数, $S_{p p^{\prime}}(\Omega)$ は同観測点における速度がほ ぼ等しい列車同士 $(270 \mathrm{~km} / \mathrm{h} \pm 0.35 \%)$ の音の相互ス ペクトル密度関数, $S_{p v}(\Omega)$ は音と振動速度の相互スペ

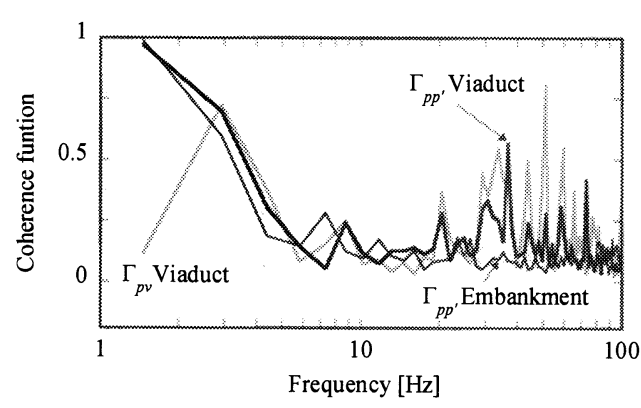

Fig. 7 Magnitude-squared coherence function; $\Gamma_{p p^{\prime}}$ (- viaduct, - embankment), $\Gamma_{p v}(-)$, train Type- $A B, U=270 \mathrm{~km} / \mathrm{h}, r \approx 29 \mathrm{~m}$.

クトル密度関数である. 式(2)(3)からそれぞれの信号間 の相関を求め、列車速度がほぼ等しい複数の列車 $(270$ $\mathrm{km} / \mathrm{h} \pm 0.35 \%$ ）について平均した值を図 7 に示す. 高 架区間においては, 音の相関 $\Gamma_{p p^{\prime}}$ に $3 \mathrm{~Hz}$ をはじめとし た複数のピークがあり, 音と振動の相関 $\Gamma_{p v}$ が高い周 波数ともほぼ一致している. すなわち，高架区閒では 列車の通過にともない定常的に発生する低周波音があ り，そのような音は $P_{f}$ による $3 \mathrm{~Hz}$ 以下の擬似音に加 え, 高架橋振動にともなう構造物音と考えられる. 一 方, 盛土区間の音の相関 $\Gamma_{p p^{\prime}}$ には, $P_{f}$ により $3 \mathrm{~Hz}$ 以下 で音の相関がある以外は, ほぼ無相関となっている. すなわち, 図 5 で観察されたような $10 \sim 40 \mathrm{~Hz}$ の低周 波音は，列車の通過にともないランダムな時閒に放射 されていると考えられる.

次に, 列車からの音の発生籄所を調べるため, 盛土 区閒の線路と平行にマイクロホンアレイを構成し，ア レイ軸と直角方向（観測点の正面方向）に指向性を持 たせた測定を行った. 目的とする音波の周波数は, $1 / 3$ オクターブバンド分析で值の大きかった $25 \mathrm{~Hz}$ ，およ び倍周波数の $50 \mathrm{~Hz}$ である. 可聴域の周波数に対して は，観測点において音響学的遠方場条件が成り立ち， 入射波を平面波と見なした遅延和型計算方法により十 分な指向性を得られるが，ここで対象とするような低 周波音は波長が長く指向性が低下する.このため, 入 射波を球面波とみなし，音波の振幅と位相を補正する ことで指向性の低下を防ぐ球面波補正法(11)を採用した。 この球面波補正法により, 指向特性の感度（音源が観 測点の正面にある場合との比) が 0.5 を上回る範囲は, $25 \mathrm{~Hz}$ に対して $\pm 14.5^{\circ}$ (車両側面の位置に換算して 8.7 m), $50 \mathrm{~Hz}$ に対して $\pm 12.5^{\circ}$ (同じく $7.4 \mathrm{~m}$ ) である. ま た，音圧変動をレベルに直す際は，時定数を短くとる 方が音源の分離には有利であるが, 中心周波数 $f_{c}$ の周 波数分析を行う際には，最低限 $1 / f_{c}$ の時間と数回の平 


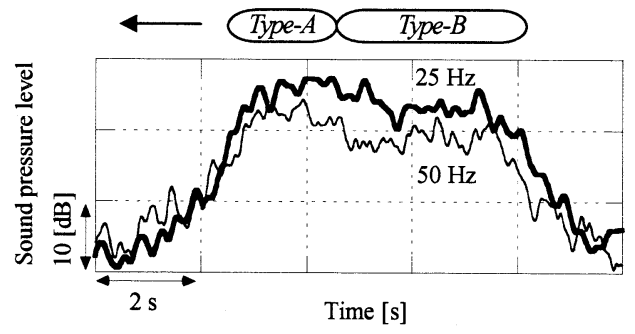

Fig. 8 Time histories of directional sound pressure level at embankment section; $U=270 \mathrm{~km} / \mathrm{h}, r=18.3 \mathrm{~m}$.

均回数が必要である.これらを考慮し, 時定数は $0.1 \mathrm{~s}$ とした. さらに, 得られた指向性音圧レベルは列車が 観測点の正面付近に来た時点の瞬時值に過ぎないため, 音源が時間的に変動するような場合, 䛊差が大きくな る(12). このため, 指向性音圧レベルは, 同条件の複数 列車 (10 列車程度) について車軸通過信号で同期をと ったアンサンブルパワー平均值である.

以上の解析方法により求めた, 指向性マイクロホン アレイの測定結果を図 8 に示す. 図 8 を見ると, 先行 する Type- $A$ 列車の方が後続の Type- $B$ 列車よりも音圧 レベルが若干大きくなる傾向を示している. また，こ こでは紙面の都合から図には示さないが, 空力的に滑 らかな形状の Type-C 列車は, Type- $A$ 列車や Type-B列 車と比較して音圧レベルは低下する傾向があり, 車体 形状によって音圧レベルに差が生じると考えられる. ただし，編成の部位に着目する限りは，多少の音圧レ ベルの変動はあるものの, 連結部／台車部／パンタ部 など形状的な特徴がある位置との対応は見られない. したがって，本地点で卓越して観測された $25 \mathrm{~Hz}$ およ び50 Hz の低周波音については, 特定の部位からの放 射ではなく，編成全体からランダムに放射されている と考えられる.

3-3 距離および速度依存性 線路沿線で観測さ れる低周波音には複数の要因が含まれるため, まず音 圧波形を $P_{f}$ と $P_{w}$ の二つの現象にフィルタで分離した 後, 特性を調べる. 図 6(a)に示した周波数分析結果か ら, $P_{f}$ に対応したフィルタはカットオフ周波数 $0.1 \sim 10$ $\mathrm{Hz}$ の 5 次バタワース・バンドパスフィルタとし, $P_{w}$ に 対応したフィルタは $10 \sim 100 \mathrm{~Hz}$ の 10 次バタワース・ バンドパスフィルタとした. フィルタ処理後の $P_{f}$ の 音圧波形は, 先頭部で $0 \longrightarrow$ 正 $\rightarrow$ 負 $\rightarrow 0$ のようなパルス波 となるため, この正負の差 (p-p 值) を $P_{f}$ の代表值 (以 下, $P_{f}$ 值) とした. なお, この現象は先頭部以外にも， 後尾部や併結部でも生じるが, 通常その中では最も大

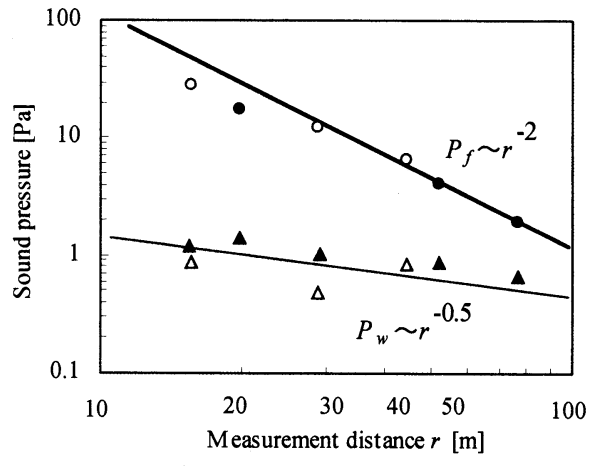

Fig. 9 Relation between measurement distance and representative value $\left(P_{f}: \bullet \circ, P_{w}: \Delta \triangle\right)$; train Type- $A B, U=$ $270 \mathrm{~km} / \mathrm{h},(\bullet \Delta)$ are viaduct section, $(\triangle \triangle)$ are embankment section.
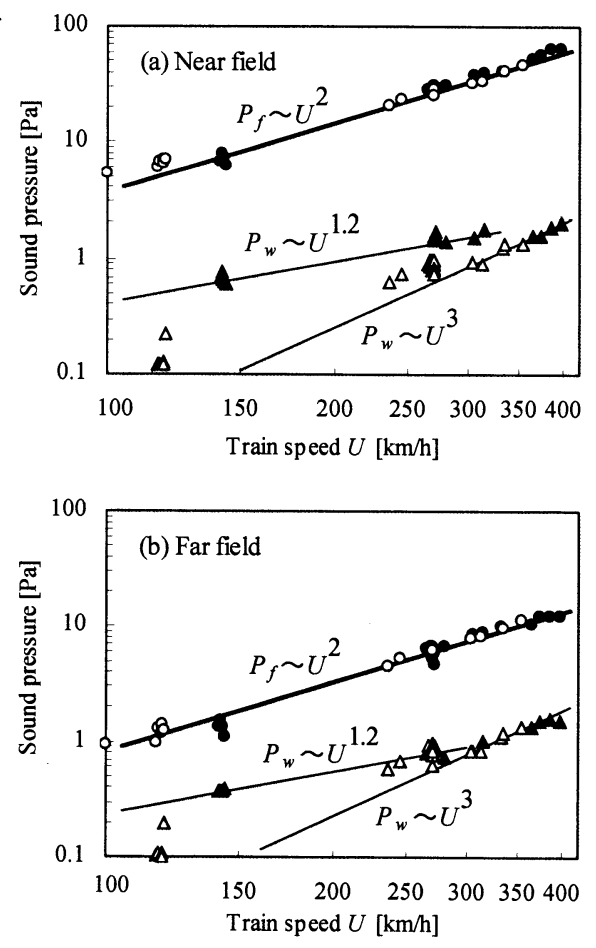

Fig. 10 Relation between train speed and representative value $\left(P_{f}: \bullet \circ, P_{w}: \Delta \triangle\right)$ at (a) $r=15.5 \mathrm{~m}$ and (b) $r=44.5 \mathrm{~m}$; $(\bullet \mathbf{)})$ are viaduct section, and $(\circ \triangle)$ are embankment section.

きい列車先頭部の $P_{f}$ 值を代表值とした. 一方, フィル 夕処理後の $P_{w}$ の音圧波形は, 連続的な波となるため, 列車が通過する閒の実効値を $P_{w}$ の代表值 $\left(P_{w}\right.$ 值) と した.

このようにして求めた $P_{f}$ 值および $P_{w}$ 值と距離 $r$ と 
(a) Viaduct section

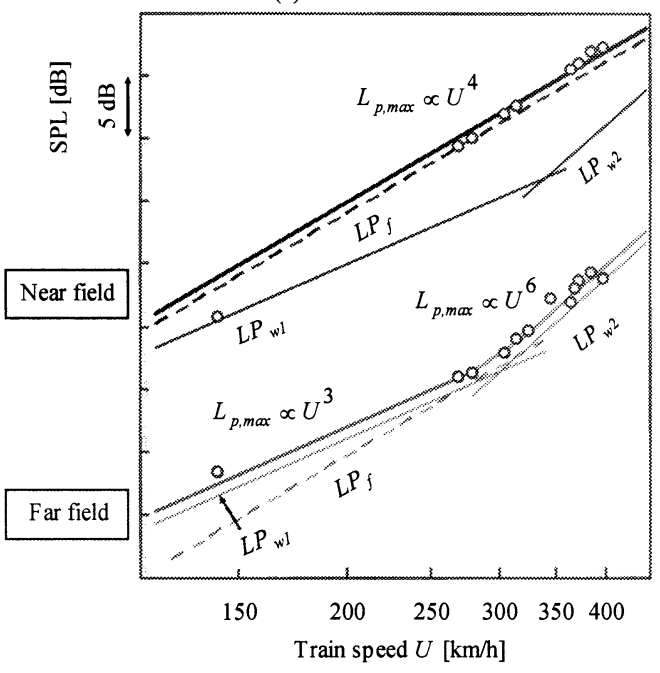

(b) Embankment section

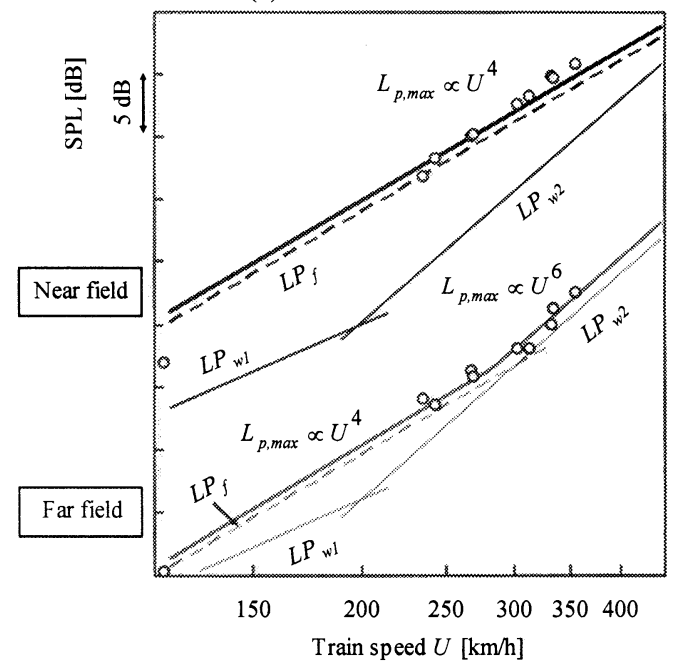

Fig. 11 Characteristics of low-frequency noise at (a) viaduct section and (b) embankment section; (o) are measured maximum sound pressure levels, $\left(-L_{p, \text { max }}\right)$ are estimated maximum sound pressure levels, $\left(---L P_{f}\right)$ are estimated sound pressure levels caused by $P_{f},\left(-L P_{w l}\right)$ are estimated sound pressure levels caused by viaduct vibration, and (-LP $(-$ are estimated sound pressure levels caused by aerodynamic source.

の関係を，図9に示す．なお，列車種別や速度が異な っても傾向は同じであったため, ここでは列車本数の 多いType-AB, 速度 $270 \mathrm{~km} / \mathrm{h}$ について平均を求めた結 果を示す.図9から, $P_{f}$ 值は距離の-2 乗程度で減衰し, $P_{w}$ 值は距離の-0.5 乗程度で減衰することが分かる.こ の $P_{f}$ 值の減衰率は式 (1) に示した理論的な特性と等 しく, $P_{w}$ 值の減衰率は音響学的な線音源と似た特性で あることが分かる. なお, $r=25 \mathrm{~m}$ 末満の近傍場にお ける $P_{f}$ 值は, -2 乗線から下方へ外れているが, これは 防音壁が圧力遮へい壁として㗢く効果や，列車の三次 元的な先頭形状の影響を強く受けているためである(7). また，近傍場では $P_{f}$ 值が $P_{w}$ 值よりも二析程度大きい が，距離减衰が $P_{f}$ 值は $P_{w}$ 值よりも大きいため, 遠方 場では $P_{f}$ 值と $P_{w}$ 值は同程度となっている. なお, $P_{w}$ 值は実効值で表しているが, $\mathrm{p}-\mathrm{p}$ 值同士で比較すれば $r$ $=50 \mathrm{~m}$ 程度以上で $P_{w}$ の成分が $P_{f}$ の成分を上回る.

次に, $P_{f}$ 值および $P_{w}$ 值と列車速度 $U$ との関係を図 10 に示す.ただし, 高架区閒と盛土区間の観測距離は, 設置場所の都合から同一ではないため，高架区間の実 測值を, 図9に示した距離依存性を使って, 盛土区間 の等価な距離へ換算している. なお，速度域によって 列車種別は Type- $A B(150 \sim 270 \mathrm{~km} / \mathrm{h})$ と Type-C (270 $400 \mathrm{~km} / \mathrm{h}$ ) の二種類あるが (表 1 参照)，同一速度では 比較的近い值を示すため, 列車種別による補正は行っ ていない. 図 10 から，いずれの観測点も $P_{f}$ 值は速度
の2 乗程度で増加しており,これは式（1）に示した 理論的な特性と等しい. 一方, $P_{w}$ 値は高架区間と盛土 区間の違いや，観測距離あるいは速度域の違いによっ て，いくつかの乗則を示している.これは， $P_{w}$ に複数 の要因が含まれており, 観測条件によって支配的な要 因が異なるためと考えられる.おおよその傾向として, 低速域では構造物音の速度乗則 $1 \sim 2$ 乗 ${ }^{(14)}$ と似た特性 を示し, 高速域では空力音の速度乗則 3 乗 ${ }^{(1)}$ 一と近づ いていると考えられる.

ここまでに得られた知見から, 高速鉄道の沿線に生 じる低周波音の一般的な特性を推定した結果を図 11 に示す．なお，プロットは低周波音の瞬時音圧レベル 最大値を実測值で示したものである.

・近傍場においては, 通過時圧力変動 $\left(L P_{f}\right)$ が音波 成分 $\left(L P_{w 1}\right.$ および $\left.L P_{w 2}\right)$ よりも大きく, 通過時圧 力変動が音圧レベル最大值を決定する.

・遠方場においては, 高架区間と盛土区間の違いや速 度域によって，支配的な要因が異なる. すなわち， 高架区間の低速域では構造物音 $\left(L P_{w 1}\right)$, 高速域で は空力音 $\left(L P_{w 2}\right)$ が支配的となって, 音圧レベル 最大值を決定する. 一方, 盛土区間の低速域では通 過時圧力変動, 高速域では空力音が支配的となって, 音圧レベル最大值を決定する.

・高架区間と盛土区間を比較すると,いずれも近傍場 では通過時圧力変動が支配的なため, 音圧レベル最 
大値に差は生じない. 遠方場では, 構造物音の差に より, $300 \mathrm{~km} / \mathrm{h}$ 程度よりも低い速度域で, 高架区 間の音圧レベルが盛土区間よりも大きくなる.ただ し，より高速域では，高架区間でも盛土区間でも空 力音が支配的となるため, 音圧レベルの差はなくな る.

$$
\text { 4. まとめ }
$$

新幹線に代表される高速列車が明かり区間を走行す る際に沿線で生じる低周波音の特性を調べた. 観測さ れた低周波音は, 主に列車の先頭部および後尾部で生 じる通過時圧力変動, 高架橋の振動にともなう構造物 音, 列車周りの空力音からなっていた. これらの組み 合わせは，列車速度・観測距離・走行区間（高架区間 と盛土区間）の違いによって異なっていた. 今回得ら れた結果から, 沿線で観測される低周波音のより一般 的な特性を示した. また, 列車速度が $300 \mathrm{~km} / \mathrm{h}$ を超え るような高速域で, かつ観測点が線路から数十 $\mathrm{m}$ 程度 離れている場合は，編成全体から放射される線音源状 の空力音が低周波音の主要因になることを示した. 今 後, 発生メカニズムの不明な低周波数域における空力 音について, 模型実験 ${ }^{16}$ や空間発展型直接数值シミュ レーションは17により研究を進める.

最後に, 本研究の現地測定にあたっては, 桻テス(技 術部)，JR 東日本コンサルタンツ (環境部) にお世話 になった. ここに記し感謝の意を表する.

\section{文 献}

(1) Ministry of the environment of Japan, Handbook to deal with low-frequency noise, (2004).

(2) Inoue, Y., Actual state and control of low frequency noise, Journal of INCE/J, Vol.23, No. 5 (1999), pp. 311-318.

(3) Ozawa, S., Studies of micro-pressure wave radiated from a tunnel exit, Railway Technical Research Repot, No. 1121 (1979).

(4) Ministry of the environment of Japan, Manual for measurement of low-frequency noise, (2000).

(5) Kikuchi, K. et al., Characteristics of low-frequency pressure waves radiated from a train passing an open section, Transactions of the Japan Society of Mechanical Engineers, Series B, Vol. 71, No. 708 (2005), pp. $49-57$.

(6) Kikuchi, K. and lida, M., Simple numerical method to calculate pressure fluctuation due to train passage, Transactions of the Japan Society of Mechanical
Engineers, Series B, Vol. 71, No. 708 (2005), pp. 58-65.

(7) Kikuchi, K. et al., Countermeasures for reducing pressure variation due to train passage in open sections, Railway Technical Research Repot, Vol. 14, No. 9 (2000), pp. 31-36.

(8) Morse, P. M. and Ingard, K. U., Theoretical Acoustics, (1986), pp. 717-737, Princeton University Press.

(9) Takami, H. et al., Low-frequency noise radiated from a high-speed train running in an open section, Proceedings of the thirteenth international congress on sound and vibration, (2006).

(10) Iwahashi, K. and Ochiai, H., Infrasound pressure meter and examples of measuring data, Journal oflow frequency noise, vibration and active control, Vol. 20, No. 1 (2001), pp. 15-19.

(11) Kikuchi, K. et al., Spherical wave correction method for applying a microphone array to low frequency sound measurement, Transactions of the Japan Society of Mechanical Engineers, Series C, Vol. 68, No. 668 (2002), pp. 137-144.

(12) Nagakura, K., The methods of analyzing shinkansen noise, Railway Technical Research Repot, Vol. 10, No. 2 (1996), pp. 29-34.

(13) Ohashi, K. and Nishimura, T., Relation between static displacement and natural frequency, Structure design document, No. 49 (1977), pp. 6-9.

(14) Nagakura, K. and Zenda, Y., Prediction model of wayside noise level of shinkansen, Proceedings of International workshop Wave 2002, (2003), pp. 237-244.

(15) Curle, N., The influence of solid boundaries upon aerodynamic sound, Proceedings of the Royal Society of London, Series A, Vol. 231, No. 1187 (1955), pp. 505-514.

(16) Takami, H. et al., Low-frequency noise by aerodynamic sources radiated from a high-speed train, Proceedings of the 56th National Congress of Theoretical and Applied Mechanics, (2007), pp. 433-434.

(17) Watanabe, D. et al., Acoustic waves emanating from transitional structures in a compressible boundary-layer for high-speed train, Proceedings of the thirteenth international congress on sound and vibration, (2006). 